\title{
Structural changes of bacterial nanocellulose pellicles induced by genetic modification of Komagataeibacter hansenii ATCC 23769
}

\author{
Paulina Jacek $^{1}$ (D) Małgorzata Ryngajłło $^{1} \cdot$ Stanisław Bielecki ${ }^{1}$
}

Received: 8 February 2019 / Revised: 9 April 2019 / Accepted: 10 April 2019 / Published online: 29 April 2019

(C) The Author(s) 2019

\begin{abstract}
Bacterial nanocellulose (BNC) synthesized by Komagataeibacter hansenii is a polymer that recently gained an attention of tissue engineers, since its features make it a suitable material for scaffolds production. Nevertheless, it is still necessary to modify BNC to improve its properties in order to make it more suitable for biomedical use. One approach to address this issue is to genetically engineer $K$. hansenii cells towards synthesis of BNC with modified features. One of possible ways to achieve that is to influence the bacterial movement or cell morphology. In this paper, we described for the first time, K. hansenii ATCC 23769 motA+ and mot $B+$ overexpression mutants, which displayed elongated cell phenotype, increased motility, and productivity. Moreover, the mutant cells produced thicker ribbons of cellulose arranged in looser network when compared to the wild-type strain. In this paper, we present a novel development in obtaining BNC membranes with improved properties using genetic engineering tools.
\end{abstract}

Keywords Komagataeibacter $\cdot$ Motility $\cdot$ Cell division $\cdot$ Bacterial nanocellulose

\section{Introduction}

Bacterial nanocellulose (BNC) synthesized by bacteria from Komagataeibacter genus is one of the most intensively studied biopolymers due to its unique properties such as high mechanical strength, chemical stability, hydrophilicity, crystallinity, and biocompatibility. BNC is the most abundant renewable organic material produced in the biosphere (Gallegos et al. 2016; Ryngajłło et al. 2018). Because of these properties, BNC has a wide range of potential biomedical applications, including wound dressings, medical implants, drug delivery, vascular grafts, and scaffolds for tissue engineering (Svensson et al. 2005; de Oliveira Barud

Electronic supplementary material The online version of this article (https://doi.org/10.1007/s00253-019-09846-4) contains supplementary material, which is available to authorized users.

Paulina Jacek

paulina.jacek@edu.p.lodz.pl

Stanisław Bielecki

stanislaw.bielecki@p.lodz.pl

Małgorzata Ryngajłlo

malgorzata.ryngajllo@p.lodz.pl

1 Institute of Technical Biochemistry, Lodz University of Technology, B. Stefanowskiego 4/10, 90-924 Lodz, Poland et al. 2016; Picheth et al. 2017). In recent years, many studies have been carried to develop BNC scaffolds for biomedical use (Wu et al. 2016; Cielecka et al. 2018; Jacek et al. 2018). Nevertheless, the main problem for tissue engineering is the limited porosity of the BNC that makes the ingrowth of the eukaryotic cells is impossible.

The properties of a BNC membrane closely depend on its morphology. One of the recent approaches aiming to change the morphology of $\mathrm{BNC}$ involves the regulation of bacterial cell movement, by using different types of electromagnetic fields (Sano et al. 2010; Baah-Dwomoh et al. 2015; Fijałkowski et al. 2015). Use of electrokinetic force to control bacterial motion of Komagataeibacter xylinus allowed for the differentiation of orientation and organization of bacterial nanocellulose fibers (Baah-Dwomoh et al. 2015). Furthermore, the intrinsic cell motility was shown to be important for pellicle formation in many species (Hölscher et al. 2015). Modification of bacterial nanocellulose structure has mainly been achieved by chemical or mechanical modifications of the cellulose matrix or via changing culturing conditions, while there are no successful results in changing the $\mathrm{BNC}$ architecture using genetic engineering tools (Chanliaud and Gidley 1999; Luo et al. 2008; Lee et al. 2014). Nevertheless, genetic engineering remains a promising approach to enable a fine control over nanocellulose synthesis towards production of diverse BNC-based biomaterials. 
The studies, which involved genetic modifications of the Komagataeibacter strains, focused mainly on the genes affecting efficiency of cellulose biosynthesis (Jacek et al. 2019). These genetic modifications included the expression of a foreign gene, the gene disruption, or gene overexpression. One of the most impressive examples of these genetic modifications is the $K$. xylinus mutant which uses lactose from whey as a carbon source, producing 28 -fold more cellulose from lactose than the wild-type strain (Battad-Bernardo et al. 2004). Another successful application of recombinant strains for bacterial nanocellulose production from wastes is a mutant of K. xylinus with enhanced ability to produce BNC from a hydrolysate of a potato pulp (Zhong et al. 2013).

Bacterial motility is a complex phenomenon playing diverse roles in biofilm formation. Most of the motile bacteria move with flagella, which is an essential multifunctional organellum involved in the initial stages of biofilm formation (Bogino et al. 2013). Bacterial cells can move through the liquid environment or translocate over the surface of solids, using various mechanisms. Bacterial chemotaxis is a kind of movement by which microorganisms efficiently and rapidly react to the changes in the chemical composition of their surroundings, approach chemically beneficial environments, and avoiding unfavorable ones (Tamar et al. 2016). The core components of the chemotaxis mechanism are universal for all motility systems and highly conserved among bacteria; however, some, often complex, variations have been identified (Szurmant and Ordal 2004). According to literature data, strains of the Komagataeibacter genus exhibit chemotactic movement (Basu et al. 2018).

In Gram-negative bacteria, cellular motility and cell division are described as one of the essential factors for biofilm formation (Pratt and Kolter 1998; Merritt et al. 2007; Niba et al. 2007). Many reports suggest that proteins MotA/MotB, ExbB/ExbD, and TolQ/TolR which form transmembrane proton channels are important in biofilm formation (Abbas et al. 2007; Søgaard-Andersen 2011; Guttenplan and Kearns 2013; Islam and Mignot 2015; Santos et al. 2015). MotA and MotB are membrane-bound proteins, which form a heterohexamer $\operatorname{Mot}_{4} / \mathrm{MotB}_{2}$ and are indispensable for bacterial motility. MotA/MotB works as the stator of the bacterial flagellar motor to couple proton influx with torque generation (Morimoto et al. 2010). It has been reported that Gram-negative bacterium Myxococcus xanthus that glides over surfaces without the aid of flagella has AglS, AglR, and AglQ, which are MotA/MotB homologs (Søgaard-Andersen 2011). Flagellar motor proteins MotA/MotB and gliding proteins AglQ-AglL/AglS share homologies with the components of the Ton and Tol systems (ExbB/ExbD and TolQ/TolR) - systems that also form proton channels and utilize a proton-motive force (PMF). However, these proteins are not involved in motility but in the active transport of substrates across the outer membrane (Cascales et al. 2001; Sun et al. 2011; Gray et al. 2015). ExbB and ExbD proteins form a complex, which is a component of the energy transducing Ton system, and which functions to harness the energy of the PMF at the cytoplasmic membrane to support active transport of iron-siderophore complexes and vitamin B12 across the outer membrane in Gram-negative bacteria (Andrews et al. 2003; Postle and Kadner 2003; Noinaj et al. 2010). TolQ and TolR together with TolA form a complex in the cytoplasmic membrane that plays an essential role in maintaining outer membrane integrity and cell division (Yeh et al. 2010; Teleha et al. 2013).

Currently, there is no information explaining potential role of MotA/ExbB/TolQ and MotB/ExbD/TolR in Komagataeibacter genus. Moreover, little is known about the role of motility and cell division on bacterial nanocellulose biosynthesis and properties. In 1976, Brown et al. first characterized the movement of Komagataeibacter hansenii cells in relation to the BNC biosynthesis (Brown et al. 1976). They observed that cell motility rate correlates with the actual biosynthesis and extrusion of bacterial nanocellulose microfibrils. Consequently, they hypothesized that cell movement is caused by the propulsion force of BNC microfibrils secretion by the bacterium (Brown et al. 1976).

Herein, for the first time, K. hansenii ATCC 23769 was modified by using genetic engineering tools, in order to obtain the loosened structure of BNC membranes. In this study, we created and investigated two overexpression mutants; $m o t A+$ and $\operatorname{mot} B+$. Moreover, to get more information about the functions of the MotA and MotB proteins, we investigated their subcellular location. Our results expanded the understanding the role of $K$. hansenii motility and cell morphology in BNC structure architecture.

\section{Materials and methods}

\section{Bacterial cell culture conditions and growth media}

Komagataeibacter hansenii ATCC 23769 was cultivated in $\mathrm{SH}$ medium (Schramm and Hestrin medium) at $30^{\circ} \mathrm{C}$. The SH medium for $K$. hansenii cultivation was used in two forms: liquid - for agitated and stationary cultures and with $2 \%(w / v)$ agar (Difco, USA) - for plate cultures. One-liter culture medium contained $20.0 \mathrm{~g}$ glucose ( $\mathrm{POCH}$, Poland), $5.0 \mathrm{~g}$ yeast extract (BTL, Poland), $5.0 \mathrm{~g}$ bacterial peptone (BTL, Poland), $2.7 \mathrm{~g}$ sodium phosphate dibasic (Chempur, Poland), $1.15 \mathrm{~g}$ citric acid (Chempur, Poland), and $0.5 \mathrm{~g}$ magnesium sulfate (Chempur, Poland). The $\mathrm{pH}$ was adjusted to 5.7 with $80 \%$ acetic acid (Chempur, Poland) before sterilization.

\section{Plasmid construction and transformation}

For motA+ and motB+ mutants, pTI99 plasmid (Hokkaido University) was used (Table 2). Initially, $m o t A$ and $m o t B$ were 
amplified from the genomic DNA of $K$. hansenii ATCC 23769 with primers pTI-motA_for, pTI-motA_rev primers and pTI-motB for, pTI-motB_rev primers, respectively (Table S1). The amplified DNA fragments and pTI99 plasmid were treated BamHI and HindIII and ligated. The resulting constructs were transformed using the heat shock method into E. coli TOP10F' cells (Froger and Hall 2008). Then, $K$. hansenii ATCC 23769 was transformed with control pTI99, pTI99-motA, pTI99-motB by electroporation, in accordance with the method used in previous studies (Jacek et al. 2018). The cells were incubated at $30^{\circ} \mathrm{C}$ for $3 \mathrm{~h}$, diluted, and transferred to $\mathrm{SH} /$ agar plates containing ampicillin $(200 \mu \mathrm{g} / \mathrm{mL})$ for screening of recombinants (Fig. S4).

\section{MotA-GFP and MotB-GFP fusion protein generation and expression}

To construct plasmids carrying the motA-gfp and motB-gfp fusion genes, the motA and $\operatorname{mot} B$ genes were amplified by PCR using the $K$. hansenii ATCC 23769 genomic DNA as a template and the motA_gfp_F, motA_gfp_R primers and motB_gfp_F, motB_gfp_R primers, respectively. The amplified DNA fragments were treated with EcoRI and BamHI (for $m o t A$ ), KpnI, and BamHI (for $\operatorname{mot} B$ ), and then ligated with a pTIE plasmid digested with the same restriction enzymes. All plasmids, including the control vector pTIE-GFP, were introduced into K. hansenii ATCC 23769 by electroporation (Hall et al. 1992).

\section{Bacterial growth curves}

To monitor cell growth and survival, viable cell counts were determined by serial dilution. A single colony was inoculated into a test tube containing $5 \mathrm{~mL}$ of liquid $\mathrm{SH}$ medium with/ without ampicillin and grown at $30{ }^{\circ} \mathrm{C}$ in static conditions. Every 24 h, 1.5\% of cellulase (Sigma-Aldrich, Denmark) was added and incubated for $3 \mathrm{~h}$ and periodically stirred. Then, serial dilutions were made in $0.9 \% \mathrm{NaCl}$ and spread on $\mathrm{SH}$ with agar plates with/without ampicillin. The experiments were carried out in triplicate.

\section{K. hansenii ATCC 23769 cell length determination}

Liquid cultures in SH medium with/without $200 \mu \mathrm{g} / \mathrm{mL}$ ampicillin of four tested $K$. hansenii ATCC 23769 strain variants (wild-type, control, $\operatorname{mot} A+$, and $\operatorname{mot} B+$ mutants) were used for cell length determination. During 6 days of incubation, $10 \mu \mathrm{L}$ portions of cells suspension were fixed to the microscope slide and stained with crystal violet, every $24 \mathrm{~h}$. From each slide, 20 pictures were taken, with use of light microscope Olympus BX 51 (Olympus, Japan) under 400 times magnification. Cells lengths were measured with Makroaufmassprogram software of at least 10 cells randomly chosen from each picture. Distribution of obtained values comprises at least 300 measurements of individual cells for each strain.

\section{E. coli TOP10F' cell length determination}

Liquid cultures in LB medium supplemented with/without $100 \mu \mathrm{g} / \mathrm{mL}$ ampicillin of four tested $E$. coli TOP10F' strain variants (wild-type, control, $\operatorname{mot} A+$, and $\operatorname{mot} B+$ mutants) were used for cell morphology determination. After $12 \mathrm{~h}$ of incubation, $10 \mu \mathrm{L}$ portions of cells suspension were fixed to the microscope slide and stained with crystal violet and observed in light microscope Olympus BX 51 (Olympus, Japan) under 1000 times magnification. Representative pictures were taken for each strain.

\section{Swarming motility assay}

Pre-cultures of three tested K. hansenii ATCC 23769 strain variants (wild-type, control and mutant) were diluted to reach optical density of 0.1 at $600 \mathrm{~nm}$. Next, $2 \mu \mathrm{L}$ portions from each equilibrated culture were inoculated onto five $0.3 \%$ agar SH plates containing $2 \%(v / v)$ cellulase (from Trichoderma reesei ATCC 26921, Sigma-Aldrich, Germany). Spots of mutant culture were accompanied by spots of wild-type and control strains on the same plates. After 3 days of incubation the diameters of colonies were measured. Measurement was repeated at $24 \mathrm{~h}$ interval two more times. Experiments were performed in five replicates and the results are given as means.

\section{Bacterial nanocellulose biosynthesis}

Liquid culture for inoculum was prepared by transferring a single bacterial colony grown on $\mathrm{SH}$ agar seed medium into $5 \mathrm{~mL}$ of a liquid $\mathrm{SH}$ medium, both with or without antibiotics, which was then incubated at $30{ }^{\circ} \mathrm{C}$ for 4 days. Five percent of the inoculum culture was introduced into a 250-mL Erlenmeyer flask containing $50 \mathrm{~mL}$ of SH medium. The culture was then incubated statically at $30{ }^{\circ} \mathrm{C}$ for 7 days. After incubation, membranes were picked and soaked in $2 \% \mathrm{NaOH}$ solution for one night, and, next in $1.5 \%$ acetic acid solution for $4 \mathrm{~h}$. Further on, the membranes were washed with distilled water until neutral $\mathrm{pH}$ was reached. After purification, the cellulose membranes were dried at $55{ }^{\circ} \mathrm{C}$ in an oven to constant weight. The productivity of $\mathrm{BNC}$ was quantified, based on the dry weight of the BNC pellicles, collected at the end of the 7-day cultivation and expressed in grams per liter. Experiments were performed in quadruplicate and the results are given as means. 


\section{Scanning electron microscopy}

Morphology and microstructural features of the membranes were investigated, using the scanning electron microscope (SEM) FEI QUANTA 250 FEG, operating at $2 \mathrm{kV}$, magnification $\times 5000, \times 20,000$, and $\times 40,000$. Prior to the analysis, BNC membranes were purified according to the methodology described by Fang et al. (Fang et al. 2015). The pellicles were freeze-dried in Christ Alpha model 1-4 LSC plus. Before the SEM analysis, the samples were coated with gold/palladium. After the observation of three biological replicates, representative micrographs were taken in triplicates for each magnification. The diameters of fibers and pores were determined with the Makroaufmassprogram, with 50 fibers and pores from the SEM micrographs.

\section{Sample preparation and fluorescence microscopy}

The cells were grown at $30^{\circ} \mathrm{C}$ for $48 \mathrm{~h}$ in $\mathrm{SH}$ medium with the appropriate antibiotics. A small portion of a culture was dropped on the slide glass and cover glass was placed. Cells were observed under a Nikon Eclipse TS100 microscope (Nikon Instruments, Tokyo, Japan). The microscope settings were as follows: excitation at $340-380 \mathrm{~nm}$, emission at 435 $485 \mathrm{~nm}$.

\section{RNA isolation and quantitative reverse transcription PCR analysis}

K. hansenii ATCC 23769 wild-type strain, pTI99, motA+, and $\operatorname{mot} B+$ were cultured in $10 \mathrm{~mL}$ test tubes containing $5 \mathrm{~mL}$ of a SH medium at $30^{\circ} \mathrm{C}$ under static conditions for 4 days. One percent $(v / v)$ cellulase (from Trichoderma reesei ATCC 26921, Sigma-Aldrich, Germany) was added to the culture and incubated for $2 \mathrm{~h}$ in $30{ }^{\circ} \mathrm{C}$. Total RNA was extracted and purified using the GeneMatrix Universal RNA Purification Kit (EURx, Poland). RNA samples were reverse transcribed with Fast SG qPCR Master Mix (2x) kit (EURx, Poland). Primers (Table S2) were designed using the NCBI's Primer-BLAST software (National Center for Biotechnology Information). RTqPCR was carried out using a CFX96TM detection system (Hercules, Bio-Rad, USA). The reverse transcription reaction was performed at $50{ }^{\circ} \mathrm{C}$ for $2 \mathrm{~min}$ and followed by conventional qPCR amplification cycles $\left(95{ }^{\circ} \mathrm{C}\right.$ for 10 min, 1 cycle; $94{ }^{\circ} \mathrm{C}$ for $15 \mathrm{~s}, 59{ }^{\circ} \mathrm{C}$ for $30 \mathrm{~s}, 72{ }^{\circ} \mathrm{C}$ for $30 \mathrm{~s}, 40$ cycles), conducted in triplicate. Transcript quantities of each target gene were normalized to the reference 16S rRNA level. The target gene expression levels were calculated using the Livak and Schmittgen equations (Livak and Schmittgen 2001):
$\Delta \mathrm{CT}$ (sample)

$=\mathrm{CT}($ target gene for sample $)-\mathrm{CT}$

(16S rRNA for sample)

$\Delta \mathrm{CT}$ (wild-type)

$=\mathrm{CT}($ target gene for wild-type $)-\mathrm{CT}$

(16S rRNA for wild-type)

$\Delta \Delta \mathrm{CT}=\Delta \mathrm{CT}($ sample $)-\Delta \mathrm{CT}($ wild-type $)$

Relative gene expression $=2^{-\Delta \Delta \mathrm{CT}}$

\section{Statistical analysis}

All data were expressed as mean \pm standard deviation (SD). The statistical analysis was calculated using Student's $t$ test, and statistical significance was set at $* p<0.05$ and $* * p<0.001$ and extreme significance was set at $* * * p<0.0001$.

\section{Results}

\section{Bioinformatical analysis of the target genes}

Based on genomic sequence of $K$. hansenii ATCC 23769 (Pfeffer et al. 2016), we have chosen two genes encoding proteins with homology to the MotA/ExbB/TolQ and $\mathrm{MotB} / \mathrm{ExbD} / \mathrm{TolR}$ proteins. The only sequences having homology with known motility-related genes were motA and motB homologs. Komagataeibacter hansenii ATCC 23769 $m o t A$ and $m o t B$ genes encode proteins of 348 and 321 amino acids, respectively. These two proteins are highly conserved among Komagataeibacter species, which suggests that they have an important cellular function. Moreover, the motA and $m o t B$ genes were found to be located in the neighboring loci, possibly forming an operon in the Komagataeibacter species (Fig. S1). We observed that in different gram-negative species belonging to Alphaproteobacteria class, motAB genes are also located in their neighboring loci (Fig. 1). Such organization is consistent with the reports regarding the organization of $m o t A$ motB genes in the Alphaproteobacteria class (Liu and Ochman 2007a; Liu and Ochman 2007b). Interestingly, the $\mathrm{N}$-terminal sequence of MotA protein and the $\mathrm{C}$-terminal sequence of MotB protein are highly conserved among Gramnegative bacteria.

BlastP analysis of MotA revealed the high level of similarity to the amino acid sequences of MotA proteins, that energize flagellar rotation in bacteria with polar flagellum (Table 1). 

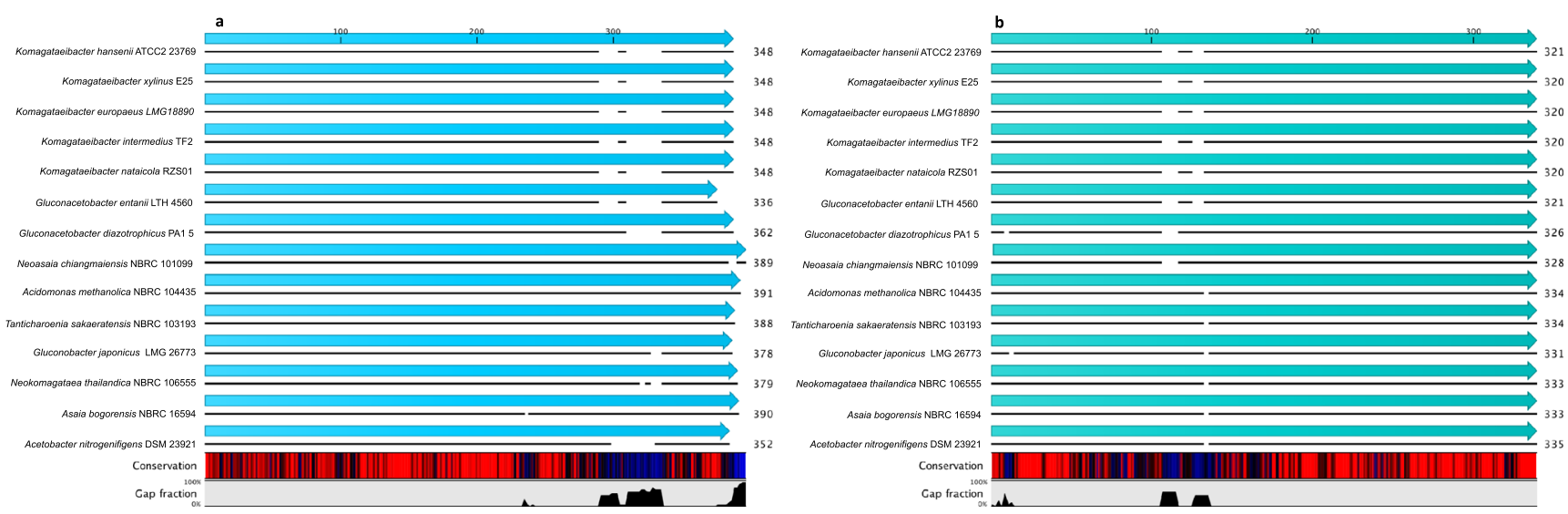

Fig. 1 Multiple sequence alignment (MSA) of $\operatorname{motA}(\mathbf{a})$ and $\operatorname{motB}(\mathbf{b})$ genes. Figures generated using CLC Sequence Viewer

Knowing different roles of the paralogous proteins, we searched for sequence similarity and predicted transmembrane topology. Results of transmembrane domains prediction suggested 4 TM domains with large cytoplasmic domain between 2nd and 3rd TMs in MotA candidate (Fig. S2 a), which would make it more similar to MotA not ExbB/TolQ proteins (they possess 3 TM domains). Overall architecture of MotB (one TM domain, OmpA-like domain at $\mathrm{C}$ terminus, mostly periplasmic) again shows closer similarity to the stator protein then to the ExbD/TolR paralogs (Fig. S2 b).

Although, bacteria of the Komagataeibacter genus do not have flagellum, sequence-based predictions show that the investigated proteins probably form a proton pump. However, the protein partner of these proteins, to which energy is transformed, is to be elucidated experimentally and, moreover, it cannot be a FliH-like flagellum protein as it is absent in Komagataeibacter.

\section{K. hansenii ATCC $23769 \operatorname{mot} A+$ and motB+ mutants' phenotype-cell size and swarming motility}

Based on the putative roles of MotA/ ExbB/TolQ and MotB/ExbD/TolR homologs (Hossain et al. 2005; Belas 2013; Teleha et al. 2013), we decided to limit K. hansenii ATCC 23769 mutant strains phenotype studies to cell lengths, motility, cellulose productivity, and pellicle microarchitecture.
We created two overexpression mutants, motA+ and $m o t B+$ (Table 2). In order to gain a better understanding of the putative function of the tested genes, we analyzed phenotype of their overexpression mutants. Firstly, we checked the morphology and observed difference in cell behavior between the wild-type strain and its overexpression mutants (Fig. 2a). The cells of wild-type $K$. hansenii ATCC 23769 were 1.00 $3.15 \mu \mathrm{m}$ in length. Overall, cells motA+ and motB+ mutants were longer in comparison to cells of wild-type. The cells of $m o t A+$ and $m o t B+$ were $1.33-6.13 \mu \mathrm{m}$ and $1.56-5.12 \mu \mathrm{m}$ in length respectively (Fig. 2b). Most mutants' cells occurred as elongated rods growing in long chains, with regions indicative of septum formation.

We observed that overexpression of motA and motB genes caused an elongate cell phenotype under normal growth conditions. In some microorganisms, swarming motility is associated with cell elongation (Fraser and Hughes 1999). Furthermore, it has been shown that some bacteria become elongated during swarming (Little et al. 2018). In Gram-negative bacteria, the Tol-Pal complex is widely conserved and may have various physiological functions such as maintenance of cell envelope integrity, interaction with outer membrane porins, expression of lipopolysaccharide surface antigens and virulence factors, facilitation of infection by filamentous DNA phage, and improvement resistance to detergents (Cascales et al. 2000; Gaspar et al. 2000; Cascales et al. 2001).

Table 1 BLASTp search with the K. hansenii ATCC 23769 MotA and MotB sequences against the genomes from Alphaproteobacteria class

\begin{tabular}{|c|c|c|c|c|c|}
\hline & Accession no. & Genome annotation & Organism & Coverage $(\%)$ & Identity $(\%)$ \\
\hline \multirow[t]{3}{*}{ MotA } & WP_012553814 & MotA/TolQ/ExbB proton channel family protein & Gluconacetobacter diazotrophicus PA1 5 & 99 & 68 \\
\hline & KXV29659 & Flagellar motor protein MotA & Gluconobacter japonicus NBRC 103476 & 98 & 59 \\
\hline & WP_086640501 & Flagellar motor protein MotA & Acetobacter tropicalis NBRC 101654 & 98 & 63 \\
\hline \multirow[t]{3}{*}{ MotB } & APO69134 & OmpA/MotB domain protein & Rhizobium gallicum IE4872 & 98 & 46 \\
\hline & WP_012567007 & Chemotaxis MotB protein & Rhodospirillum centenum SW & 95 & 48 \\
\hline & WP_041039755 & Flagellar motor rotation protein MotB & Magnetospirillum magnetotacticum MS-1 & 99 & 46 \\
\hline
\end{tabular}


Table 2 Bacterial strains and plasmids used in this study

\begin{tabular}{|c|c|c|}
\hline Strains/plasmids & Relevant characteristics & Reference/source \\
\hline \multicolumn{3}{|l|}{ Strains } \\
\hline $\begin{array}{l}\text { Eschericha coli } \\
\text { TOP10F' } \\
\text { Komagataeibacter hansenii }\end{array}$ & $\begin{array}{l}F^{\prime} l a c \mathrm{I}^{\mathrm{q}} \operatorname{Tn} 10\left(\mathrm{Tet}^{\mathrm{R}}\right) \text { mcrA } \Delta(\text { mrr-hsd } \mathrm{RMS}-m c r \mathrm{BC}) \phi 80 \text { lac } \mathrm{Z} \Delta \mathrm{M} 15 \Delta \text { lacX74 } \\
\quad \text { deo } \mathrm{R} \text { recA1 araD139 } \Delta(\text { ara-leu }) 7697 \text { galU galK rpsL }\left(\mathrm{Str}^{\mathrm{R}}\right) \text { end } \mathrm{A} 1 \text { nup } \mathrm{G}\end{array}$ & Invitrogen, USA \\
\hline ATCC 23769 & Wild-type strain & Hokkaido University, Japan \\
\hline \multicolumn{3}{|l|}{ Plasmids } \\
\hline pTI99 & Creation pTI99-motA and pTI99-motB vectors & Hokkaido University, Japan \\
\hline pTIE & Creation MotA-GFP, MotB-GFP vectors & Hokkaido University, Japan \\
\hline pTI99-motA & K. hansenii motA+ overexpression mutant & This study \\
\hline pTI99-motB & K. hansenii motB+ overexpression mutant & This study \\
\hline pTIE-MotA-GFP & K. hansenii MotA-GFP overexpression mutant & This study \\
\hline pTIE-MotB-GFP & K. hansenii MotB-GFP overexpression mutant & This study \\
\hline
\end{tabular}

Filamentous phenotype implies a defect in cell division such that cells continue to grow in the absence of septation. Cells that seem to be elongated can also form by the failure of cell separation following successful division, consequently resulting in cells that are connected end-to-end in long chains (Kearns and Losick 2005; Patrick and Kearns 2008). Teleha et al. reported that tolQ and tolR E. coli overexpression mutants' cells display an elongated phenotype, suggesting role of these genes in cell division (Teleha et al. 2013). Therefore, we decided to investigate the effect of $m o t A$ and $m o t B$ overexpression on E. coli TOP $10 F^{\prime}$ cell morphology. No differences were observed in cell morphology between the motA+, motB+ mutants and the control with pTI99 and the wild-type strain (Fig. S3).
In order to test if cells with increased motility could form cellulose pellicles with loosened network, we performed motility assay for $K$. hansenii ATCC 23769 WT, control, and mot $A+\operatorname{mot} B+$ mutants. Motility assay showed that $K$. hansenii ATCC 23769 is able to spread over moist surfaces in a process called "swarming." Observation of the bacterial colonies spreading on the soft agar is commonly interpreted as presence of swarming motility in the tested microorganisms.

The swarming motility of $m o t A+$ and $m o t B+$ mutants, control, and wild-type $K$. hansenii ATCC 23769 strain was analyzed over 3 subsequent days (Fig. 3a). The cells of the wildtype strain formed colonies with thin spreading edges, whereas the motA+ and motB+ cell mutants formed irregular spreading colonies on agar. Based on motility assay, we a

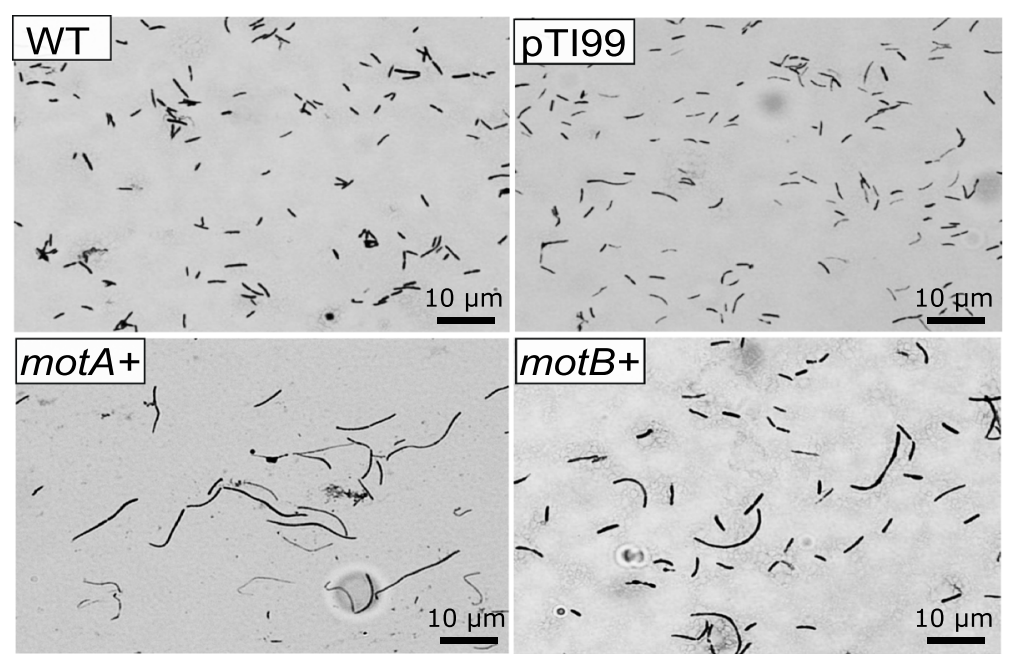

b

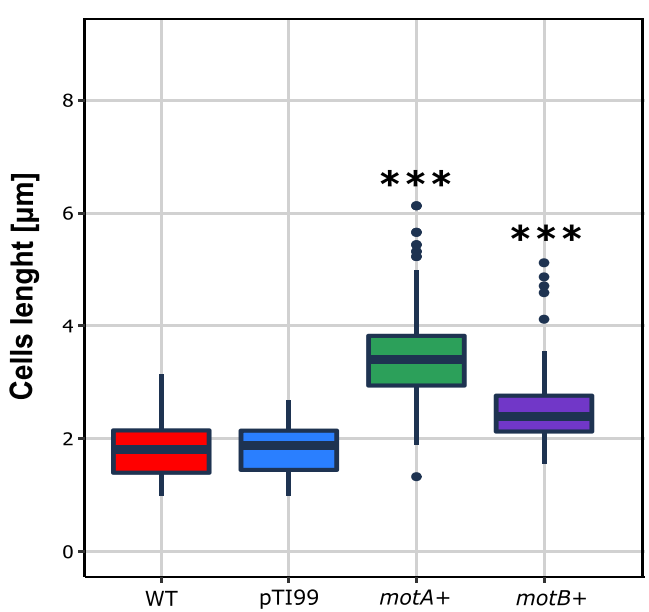

Fig. 2 Komagataeibacter hansenii ATCC 23769 cell size estimation. a Example microphotographs of $K$. hansenii ATCC 23769 cells after crystal violet staining (magnification $\times 1000$ ): wild-type, control with empty plasmid, and $\operatorname{mot} A+, \operatorname{mot} B+$ cells are shown. b Mean cells lengths are given in micrometer, measured from 20 images taken every
$24 \mathrm{~h}$ starting from 2 nd to 7 th day of incubation (120 fields of view for each sample). Error bars represent SD. Significance was determined using Student's $t$ test: $(* *)$ indicates $p<0.001$ and (***) indicates $p<0.0001$ compared to the wild-type strain 

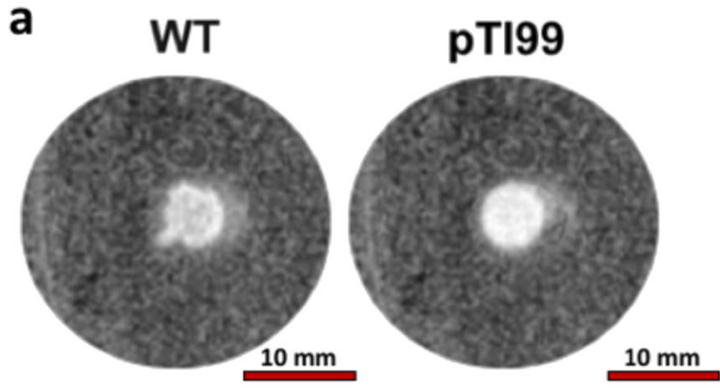

$\operatorname{mot} A+$

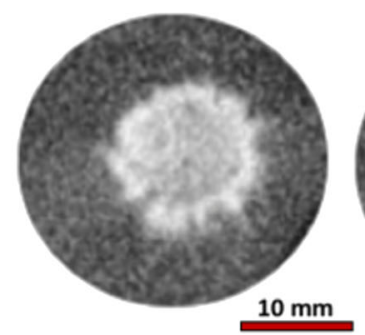

motB+

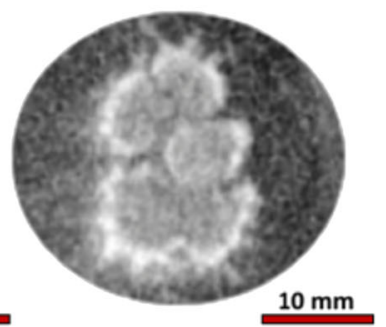

Fig. 3 Motility assay results. a Example photograph of colonies formed by $K$. hansenii ATCC $23769 \mathrm{WT}$, control, and $m o t A+$ and $m o t B+$ on soft agar $(0.3 \%)$. Images taken on 5 rd day of incubation. b Changes in colonies' size [mm] measured every $24 \mathrm{~h}$, starting from $3 \mathrm{nd}$ and

observed a threefold increase in speeding of mutant colonies in comparison to the WT and the controls (Fig. 3b).

Swarming typically involves collective movement of a dense population of bacteria cells. It is a common manner of motility that allows bacteria to rapidly colonize a surface, leading to the biofilm formation (Donlan 2002). In some microorganisms, swarming motility is associated with cell elongation (Fraser and Hughes 1999). Furthermore, it has been shown that some bacteria become elongated during swarming (Little et al. 2018).

\section{Characterization of BNC membranes produced by mutant strains}

To understand the importance of the effect of overexpression of $m o t A$ and $\operatorname{mot} B$ genes on the structure of BNC membranes, we performed the SEM imaging. Both mutants produced membranes with significantly loosened network (Fig. 4, left column), which was confirmed by estimating the diameters of 50 pores (Fig. 4, middle column). Interestingly, the mutant $m o t B+$ produced membranes with pores almost 9 times larger when compared to the wild-type strain. The pore sizes of membranes produced by the wild-type $K$. hansenii ATCC 23769 and pTI99 control were $0.16 \pm 0.06$ and $0.15 \pm$ $0.06 \mu \mathrm{m}$, and by motA+ and motB+ mutants were $0.99 \pm$ $0.34 \mu \mathrm{m}$, and $1.48 \pm 0.49 \mu \mathrm{m}$, respectively. We also investigated the relationship between motility, length of the bacterial cells, and the size of the fiber thickness in mutants and WT (Fig. 4, right column). MotA+ and mot $B+$ mutants produced b

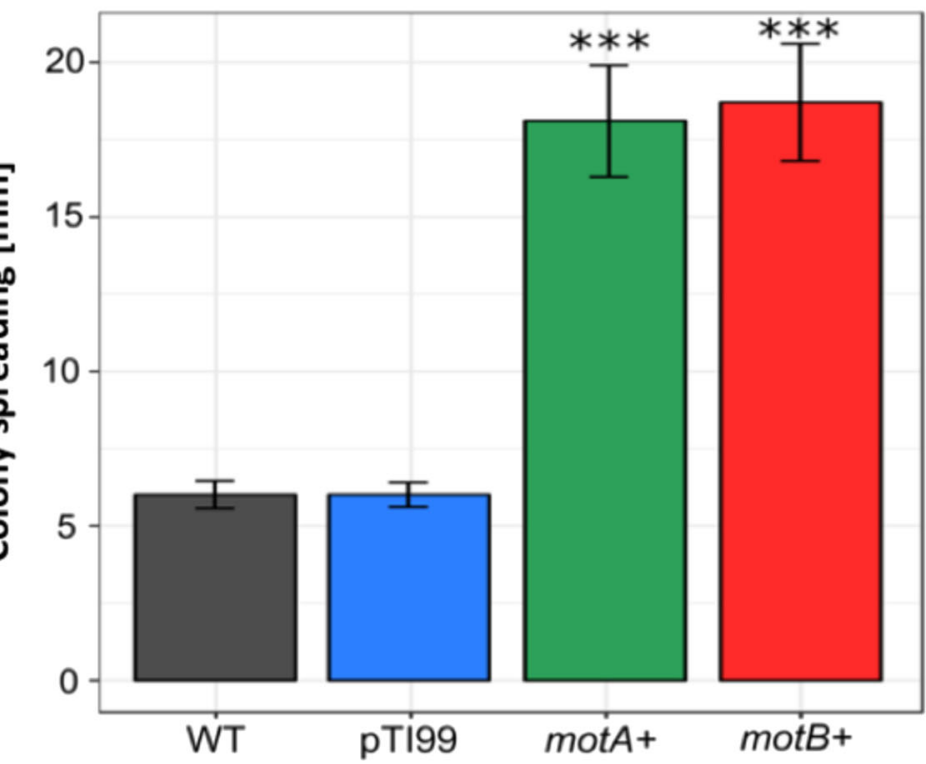

finishing on 5th day of incubation. Mean values were calculated from five biological replicates; error bars represent standard deviations. Significance was determined using Student's $t$ test: (***) indicates $p<0.0001$ compared to the wild-type strain

thicker fibers compared to the wild-type strain. An average cellulose fibers' size in the WT strain and motA+, motB+ mutants was about $0.06 \pm 0.02,0.148 \pm 0.05$, and $0.105 \pm$ $0.03 \mu \mathrm{m}$, respectively.

High porosity is significant feature of 3-D biopolymer scaffolds used in tissue engineering because of its essential effects on cell growth. It is generally assumed that pore size of a scaffold may affect the cell adhesion and proliferation (Bäckdahl et al. 2006). Material obtained from mutants has a great application potential as a scaffold in tissue engineering due to the fact that it has significantly enlarged pores when compared to wild-type membranes and there are possibilities to control the pores sizes.

\section{Impact of bacterial motility and cell morphology on bacterial nanocellulose production}

Before comparing the yields of bacterial nanocellulose, we examined the growth rates of $m o t A+$ and $\operatorname{mot} B+$ mutants over a period of 6 days to investigate the effect of $m o t A$ and $m o t B$ genes overexpression on the cell growth. We decided to monitor the growth rate of each culture by its colony-forming unit (CFU) since, under the static growth condition, cells producing cellulose are fixed in the cellulose membrane formed the surface of the medium, which makes monitoring cell growth by optical density imprecise.

The growth curves of Komagataeibacter hansenii ATCC 23769 wild-type and its overexpression mutants showed that there were slight differences of growth of $\operatorname{mot} A+, \operatorname{mot} B+$, 

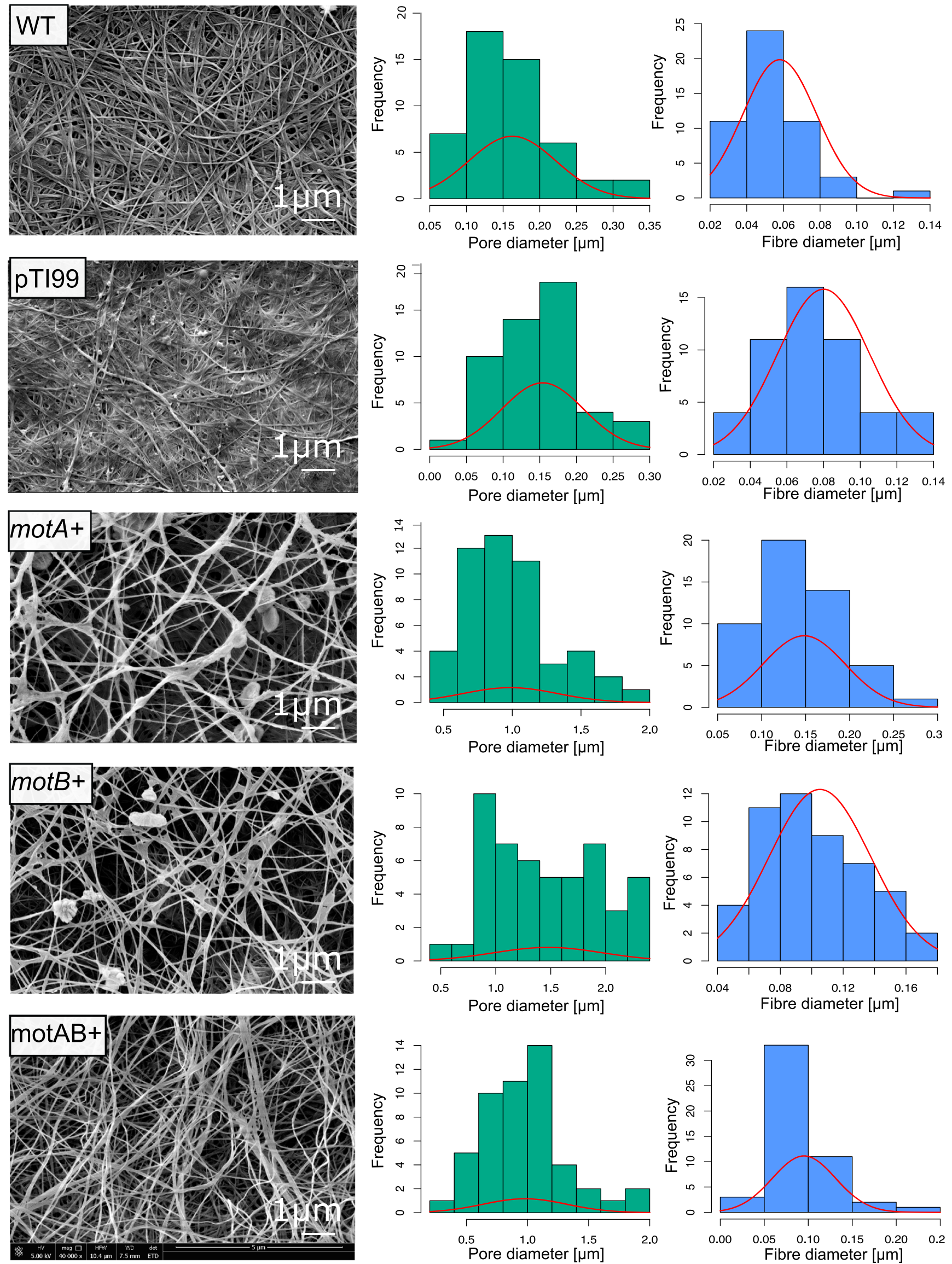

Springer 
Fig. 4 Characterization of BNC membranes: left column scanning electron micrographs (ETD detector, magnification $\times 40,000$ ), middle column: pores diameters distribution (50 measurements for each sample), right column: fibers diameters distribution (50 measurements for each sample)

when compared with the wild-type strain. Up to day 4 , the growth rates of $m o t A+$ and $m o t B+$ mutants were slightly higher than those of WT; however, at the end of day 6 , all of the mutants and WT reached similar CFU values (Fig. 5a).

In order to investigate the efficiency in the production of BNC by mutants, wild type, pTI99, and $m o t A+, \operatorname{mot} B+$ were grown for 3 days in $5 \mathrm{~mL} \mathrm{SH}$ medium under static conditions; for overexpression mutants, ampicillin $(200 \mu \mathrm{g} / \mathrm{mL})$ was added, and then $5 \%$ of inoculum was transferred into $50 \mathrm{~mL}$ SH medium. After growth under static conditions for 7 days,
BNC membranes were harvested and purified (Fig. 5b) and their dry weights were determined. The results shown in Fig. $5 \mathrm{c}, \mathrm{d}$ revealed that the mutants produced more $\mathrm{BNC}$, when compared with the wild-type. MotA+ and motB+ mutants produced $6 \%$ and $20 \%$ more cellulose respectively, in contrast to WT and pTI99. These results suggest that overexpression of motA and motB genes not only affected the morphology, but also the yield, of bacterial nanocellulose production.

There is no information explaining the impact of motility and cell length on BNC biosynthesis by $K$. hansenii ATCC 23769. Our results indicate that motA, motB genes may have an impact not only on the BNC structure but also on the cellulose yield. In the latest work, Basu et al. also noticed that there is a correlation between cell motility and cellulose yields (Basu et al. 2018). Several studies suggest that motility and cell size are involved in biofilm formation in many different a

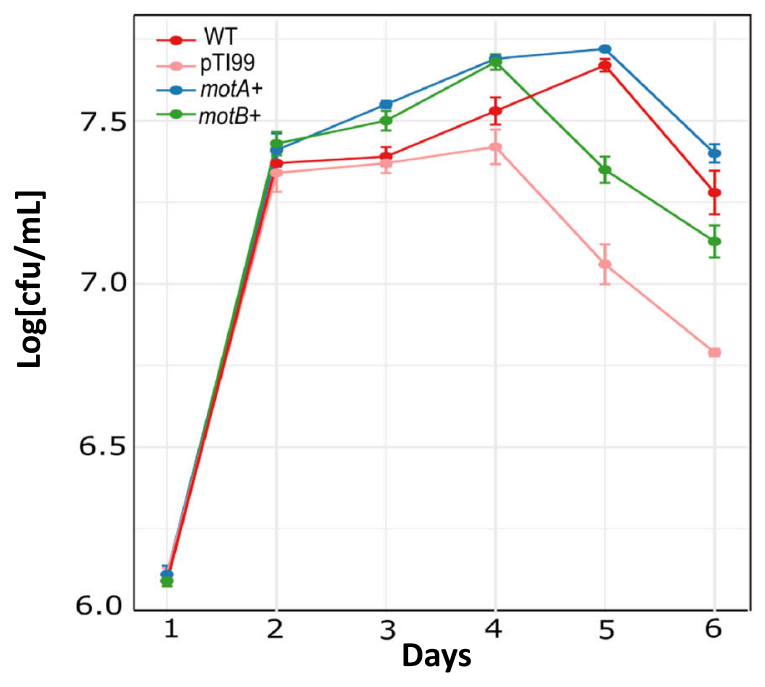

C

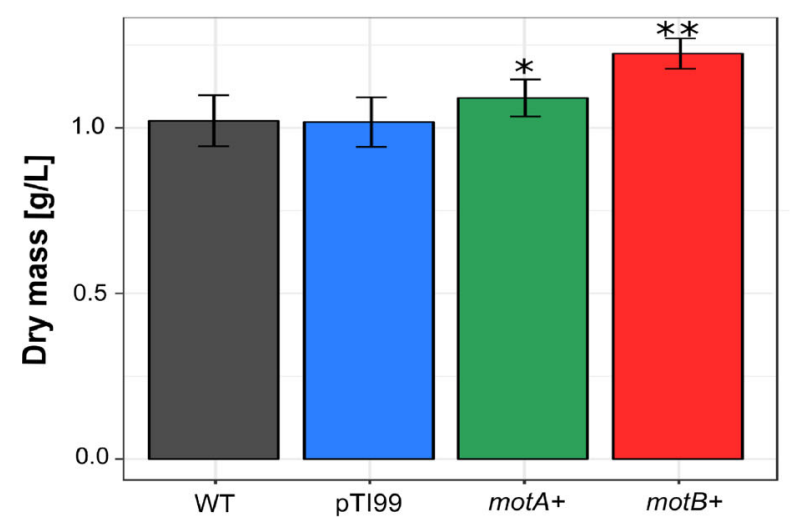

Fig. 5 Characterization of $K$. hansenii ATCC 23769 WT, control with empty plasmid, and motA+ and motB+ strains. a Growth curve. b Morphology of a typical cellulose pellicle produced by $K$. hansenii ATCC $23769 \mathrm{WT}$ and mutant strains after 7 days in $50 \mathrm{ml} \mathrm{SH}$. c Bacterial nanocellulose productivity of $K$. hansenii ATCC 23769 WT and mutant strains, shown as pellicle dry mass after a 7-day incubation b
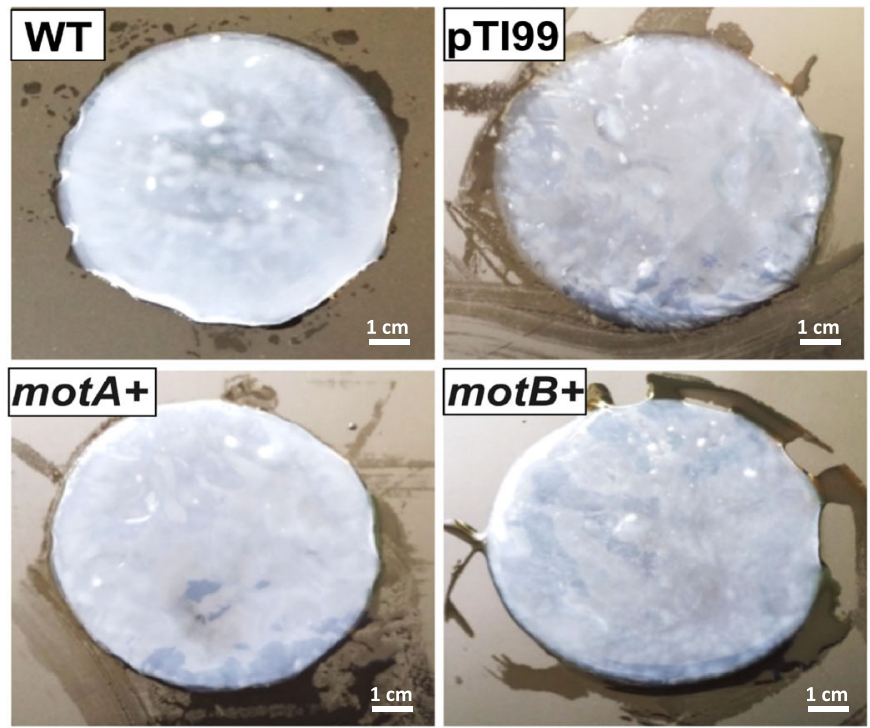

d
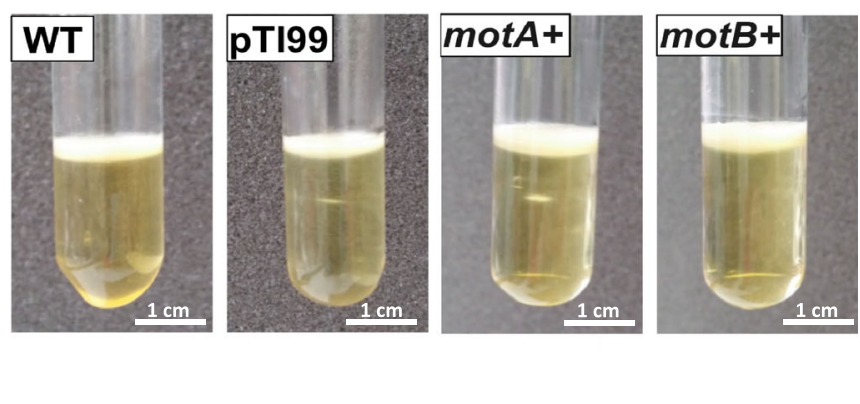

in $50 \mathrm{~mL} \mathrm{SH}$ media. d Example photographs of culture in $5 \mathrm{~mL} \mathrm{SH}$ medium after 7 days. Mean values were calculated from four biological replicates; error bars represent standard deviations. Significance was determined using Student's $t$ test: $(*)$ indicates $p<0.05$ and (**) indicates $p<0.001$ compared to the wild-type strain 
microbes (O’Toole and Kolter 1998; Pratt and Kolter 1998; Choy et al. 2004; Merritt et al. 2007; Niba et al. 2007). It has been demonstrated that deletion mutant of motA was nonmotile and displayed reduced ability to form biofilm (Hossain and Tsuyumu 2006). Further, it was reported that the tonB1 gene of Pseudomonas aeruginosa is not only required for transport of molecules involved in biofilm formation, but also in quorum sensing (Abbas et al. 2007).

\section{Subcellular localization of MotA and MotB proteins}

To investigate the localization of MotA and MotB proteins in K. hansenii ATCC 23769 cells, we constructed expression systems for green fluorescent protein (GFP) fused MotA and MotB proteins. These $\mathrm{C}$-terminal fused constructs were designated MotA-GFP and MotB-GFP, respectively. As expected, localization of MotA-GFP and MotB-GFP occurred at the cell pole (Fig. 6a). Moreover, we have observed that both MotA and MotB have a polar location when cells are short, whereas bipolar when cells are longer (Fig. 6b).

\section{Relative gene expression}

In order to evaluate the influence of overexpression of the motA and motB genes in K. hansenii ATCC 23769 cells, RTqPCR experiments were performed with the wild-type, $m o t A+$ and $m o t B+$ genes. In addition, transcript levels of molecular chaperons (groES, groEL, dnaJ), translation factors (if $2, t u$ ), and genes involved in the bacterial nanocellulose biosynthesis (ugp, bcsA) were evaluated (Fig. 7). The results of this analysis showed that the transcript levels of motA and $m o t B$ were higher, both in $m o t A+$ and in $\operatorname{mot} B+$ mutants. Furthermore, the relative expression of groES, groEL, dnaJ, if 2 , and $t u$ was increased in both mutants, nevertheless the highest in $m o t B+$ mutant. In $m o t A+$ and $m o t B+$ mutants, the expression level of UDP-glucose pyrophosphorylase ( $u g p)$ was significantly upregulated, which suggests an enhanced UDP-glucose synthesis. Bacterial nanocellulose is synthesized from UDP-glucose by the action of cellulose synthase (bcs) multimeric enzyme (Jacek et al. 2019). MotA+ and $m o t B+$ are expressing $b c s A$ at a 2.1 and 0.8 -fold higher level respectively, in comparison to the wild-type strain.

\section{Discussion}

Herein, for the first time, a new approach in modifying the structure of bacterial nanocellulose using genetic engineering tools is presented. We chose two genes encoding proteins which are homologs of MotA/ExbB/TolQ and MotB/ExbD/ TolR proteins. Homologs of selected proteins are specific for Gram-negative bacteria and are involved in diverse activities. Two motility proteins MotA and MotB are essential for rotating the proton-driven flagellar motor (Kojima and Blair 2004). Furthermore, ExbB and ExbD participates in active transport mechanisms in TonB system, responsible mainly for macromolecules and complexes with ferric ions uptake but as well saccharides and DNA may be transported by these systems (Braun and Braun 2002; Maki-Yonekura et al. 2018). Third role of such systems was most frequently observed for TolA/TolQ homologs with its involvement in cell division regulation but by yet-unknown mechanism (Germon et al. 2001; Gerding et al. 2007).

Very high level of $m o t A$ and $m o t B$ sequence conservation between Komagataeibacter strains suggests involvement of the tested genes in yet-unknown but important mechanism, presumably connected with single cellulose chain secretion and further assembly in bacterial nanocellulose ribbon. Although bioinformatic studies have proven that the tested genes are more closely related to $m o t A$ and $m o t B$ homologs, we found them to be involved not only with bacterial movement but also in diverse activities, such as cell division, productivity of cellulose, and creation of 3-D cellulose network with larger pores and thicker fibers.

Our results suggested that cell size elongation influenced cellulose ribbons diameter and spatial arrangement as well. MotA+ and $m o t B+$ mutants produced membranes with loosened structure and thicker fibers compared to the wild-type strain. Therefore, this result gives a new line of evidence that cellulose fiber assembly occurring outside the K. hansenii ATCC 23769 cells is correlated with cell size. Cell elongation lead to fiber thickening. A possible explanation of this phenomenon could be in this manner. Bacteria grow by cell division. Cellulose networks are supposed to form together with cell division (Watanabett and Yamanaka 1995). It is considered that, in every cell division, a ribbon is divided into two in the horizontal direction; thus, this action is reiterated with every cell division and with every separation of cells, and these reiterations result in networks of cellulose ribbons (Yamanaka et al. 1989). The same effect with cell elongation induced by, e.g., chloramphenicol addition to the medium was previously described to induce loosening of cellulose network (Yamanaka et al. 2000).

Interestingly, motA+ and motB+ overexpression mutants showed significantly increased cellulose productivity as well. Several studies suggest that motility and cell size are involved in biofilm formation in many different microbes (O'Toole and Kolter 1998; Pratt and Kolter 1998; Choy et al. 2004; Merritt et al. 2007; Niba et al. 2007). It has been demonstrated that deletion mutant of motA was non-motile and displayed reduced ability to form biofilm (Hossain and Tsuyumu 2006). Despite the fact that both motA and $\operatorname{mot} B$ play an essential role in the biofilm formation in Gram-negative bacteria, there is no evidence of the role of these genes in Komagataeibacter genus. 
a
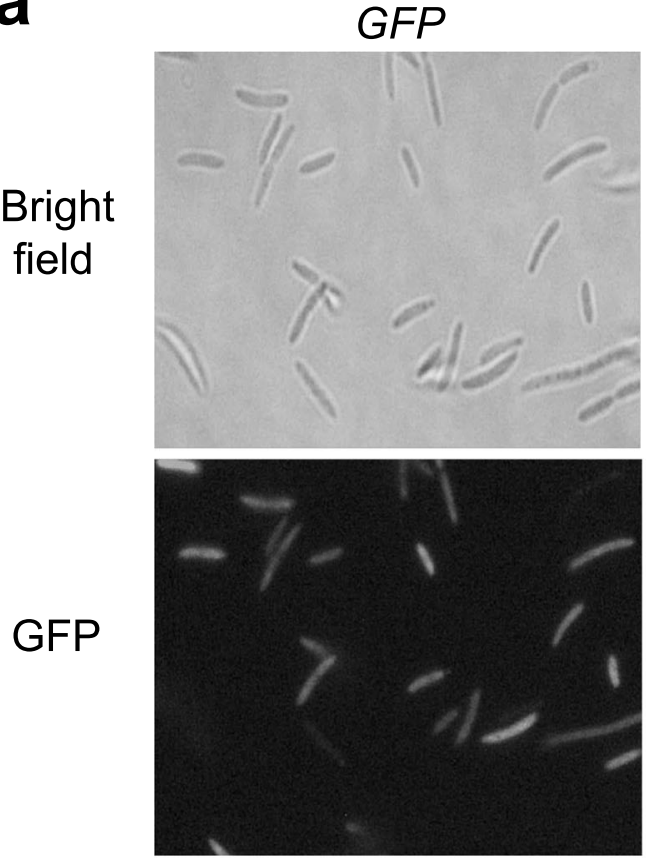

Schematic

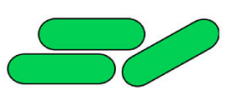

b

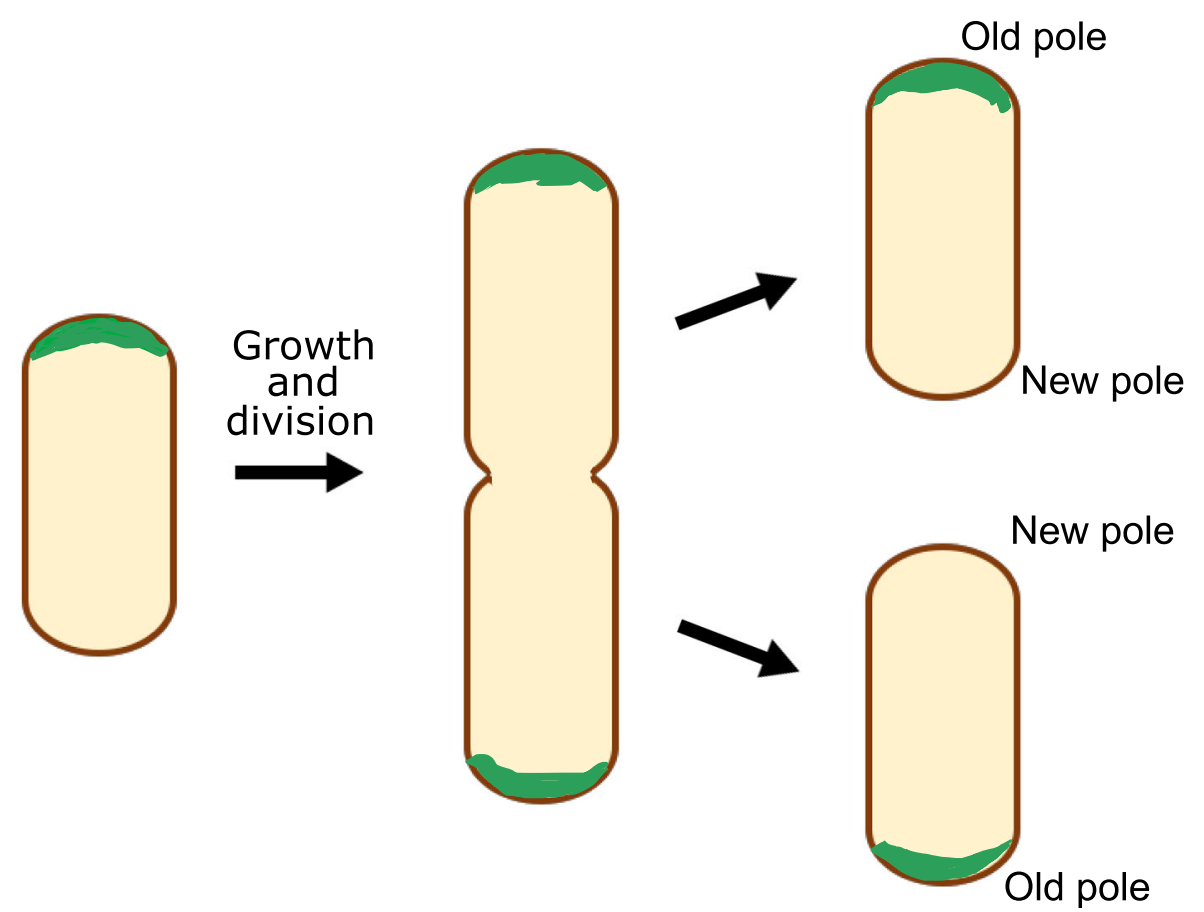

MotA-GFP
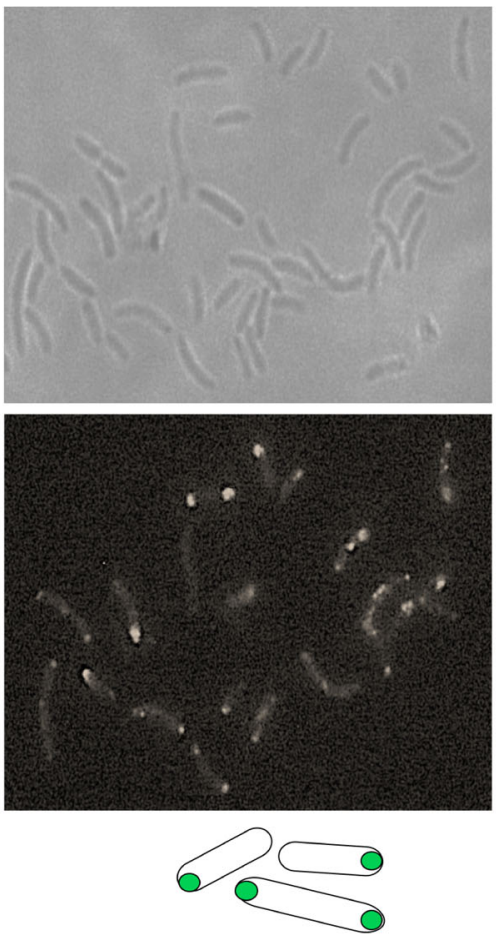

MotB-GFP
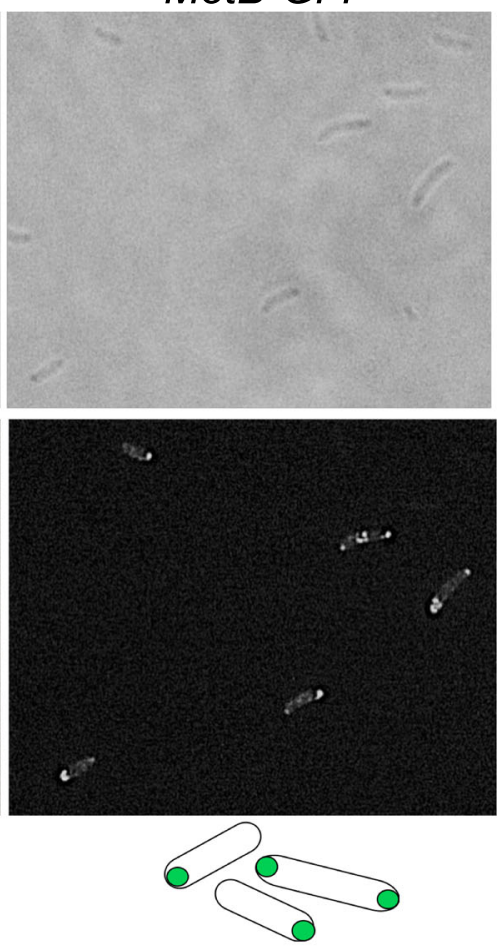

Fig. 6 a Subcellular localisation of MotA and MotB proteins in K. hansenii ATCC 23769. b Possible bipolar to old-pole localization of MotA and MotB produced by a cell division event

Localization of MotA-GFP and MotB-GFP occurred at the cell pole. Furthermore, we have observed that both MotA and MotB have a polar location when cells are short, while bipolar when cells are longer. Similar results were obtained in bacteria with polar flagella (Koerdt et al. 2009; Wang et al. 2013). In Vibrio alginolyticus, PomA and PomB proteins, which are MotA and MotB homo$\log$ s, are localized to a cell pole dependent on the 


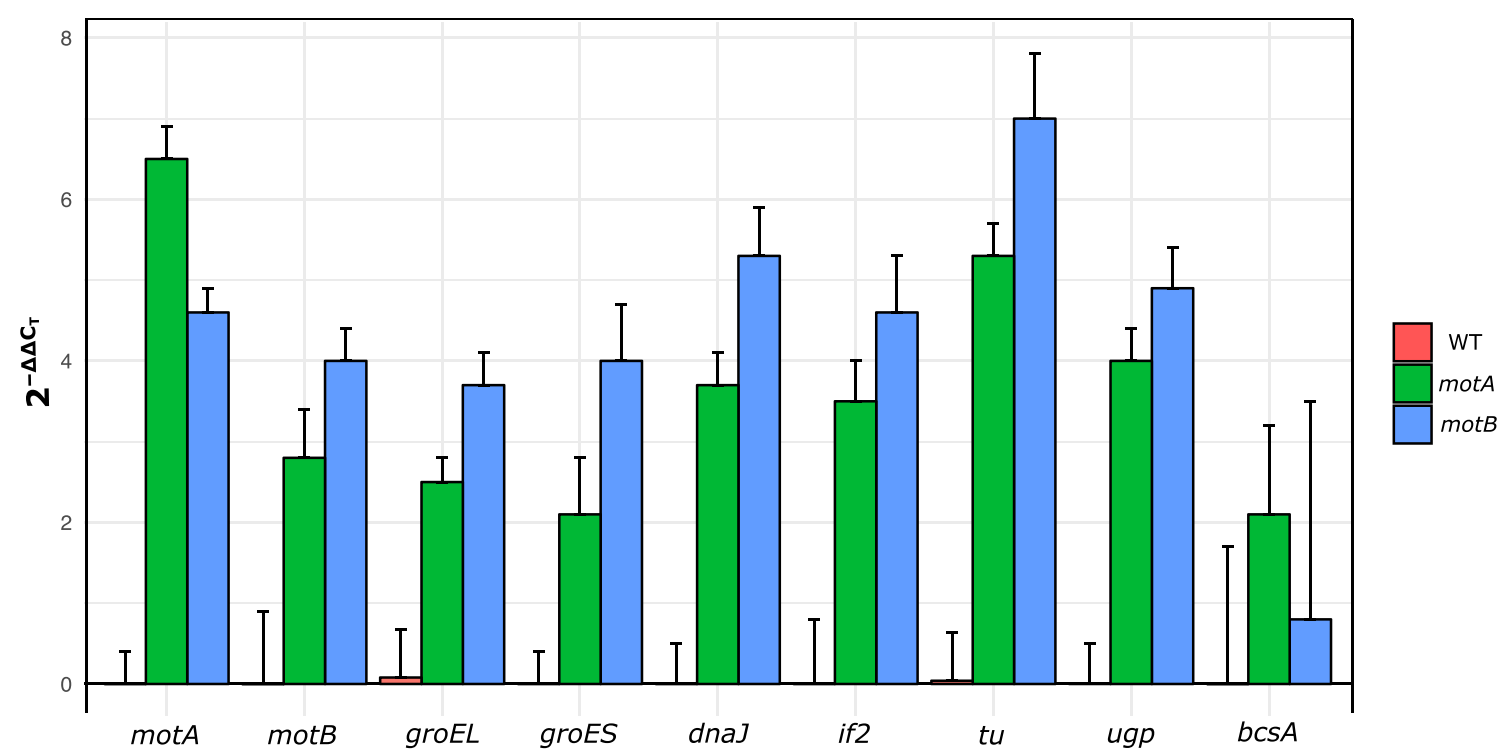

Fig. 7 The relative expression of selected genes from qPCR data in $m o t A+$ and $m o t B+$ strains, where the expression levels in the mot $A+$ and $m o t B+$ samples were normalized with the mean expression in wildtype samples. Samples were normalized to wild-type samples with the
Livak method and $16 S r R N A$ gene was used as the reference gene. Mean values were calculated from three biological replicates; error bars represent standard deviations presence of the polar flagellum (Fukuoka et al. 2005; Kojima 2015). The polar localization of proteins is a crucial functional feature, since it is critical for correct performance of several essential cellular processes including growth and cell division as well as cell motility (Shapiro et al. 2002; Ryan and Shapiro 2003; Treuner-Lange and Søgaard-Andersen 2014). Similar localization of Mot proteins was observed for in bacteria with polar flagella (Koerdt et al. 2009). Since, bacteria from the Komagataeibacter genus do not have flagella, we suppose that this feature is not essential for BNC production and maybe was reduced during evolution.

The RT-qPCR results indicated that the overexpression of motA and motB genes in K. hansenii ATCC 23769 strain resulted in a higher expression level of motA, motB, groEs, groEL, dnaJ, if $2, t u, u g p$, and $b s c A$ genes. GroES/EL and DnaJ contributes to diverse cellular functions, including stress responses, motility, and pathogenesis (Shi et al. 1992; Susin et al. 2006). Translational factors are involved in many mechanisms, including replication, transcription, RNA processing, DNA repair, regulation of translation, malignant transformation, and regulation of cell growth and development (Caldas et al. 2000; Madison et al. 2012). Translation initiation factor (if2) and translation elongation factors $(t u)$, in addition to their role in translation, might be implicated in protein folding and protection from stress. Several studies have reported upregulation of molecular chaperons and stress-responsive genes, e.g., by ethanol (Okamoto-Kainuma et al. 2004).
Furthermore, the expression level of $u g p$ and $b c s A$ genes was upregulated in the motA+ and the motB+ mutants, which might explain the observed increase in the efficiency of BNC production. These observations are in agreement with the previous reports suggesting that MotA and MotB proteins are important in biofilm formation (Hossain and Tsuyumu 2006).

In this study, we show for the first time the functional role of MotA and MotB in the regulation of bacterial cellulose production and creation of porous BNC network. By control of $K$. hansenii motility and cell size, it is possible to direct cells to produce well-defined three-dimensional scaffold for tissue regeneration and repair. Therefore, we believe that it is necessary to discover and examine other genes related to cell division or motility, as this may in the future allow obtaining cellulose with desirable properties depending on the application.

Acknowledgements We would like to thank Prof. K. Tajima for kindly providing the pTI99, pTIE plasmids, and K. hansenii ATCC 23769 strain. We also thank Dr Katarzyna Kubiak for valuable discussion at the initial steps of the studies. Furthermore, we would like to thank Jolanta Płoszyńska for her help with the media preparation.

\section{Compliance with ethical standards}

Conflict of interest The authors declare they have no conflict of interest.

Ethical approval This article does not contain any studies with human participants or animals performed by any of the authors. 
Open Access This article is distributed under the terms of the Creative Commons Attribution 4.0 International License (http:// creativecommons.org/licenses/by/4.0/), which permits unrestricted use, distribution, and reproduction in any medium, provided you give appropriate credit to the original author(s) and the source, provide a link to the Creative Commons license, and indicate if changes were made.

\section{References}

Abbas A, Adams C, Scully N, Glennon J, O'Gara F (2007) A role for TonB1 in biofilm formation and quorum sensing in Pseudomonas aeruginosa. FEMS Microbiol Lett 274:269-278. https://doi.org/10. 1111/j.1574-6968.2007.00845.x

Andrews SC, Robinson AK, Rodríguez-Quiñones F (2003) Bacterial iron homeostasis. FEMS Microbiol Rev 27:215-237

Baah-Dwomoh A, Rolong A, Gatenholm P, Davalos RV (2015) The feasibility of using irreversible electroporation to introduce pores in bacterial cellulose scaffolds for tissue engineering. Appl Microbiol Biotechnol 99:4785-4794. https://doi.org/10.1007/ s00253-015-6445-0

Bäckdahl H, Helenius G, Bodin A, Nannmark U, Johansson BR, Risberg B, Gatenholm P (2006) Mechanical properties of bacterial cellulose and interactions with smooth muscle cells. Biomaterials 27:21412149. https://doi.org/10.1016/j.biomaterials.2005.10.026

Basu A, Vadanan SV, Lim S (2018) A novel platform for evaluating the environmental impacts on bacterial cellulose production. Sci Rep 8: 1-8. https://doi.org/10.1038/s41598-018-23701-y

Battad-Bernardo E, McCrindle SL, Couperwhite I, Neilan BA (2004) Insertion of an E. coli lacZ gene in Acetobacter xylinus for the production of cellulose in whey. FEMS Microbiol Lett 231:253260. https://doi.org/10.1016/S0378-1097(04)00007-2

Belas R (2013) When the swimming gets tough, the tough form a biofilm. Mol Microbiol 90:1-5

Bogino PC, Oliva M de las M, Sorroche FG, Giordano W (2013) The role of bacterial biofilms and surface components in plant-bacterial associations. Int J Mol Sci 14:15838-15859

Braun V, Braun M (2002) Active transport of iron and siderophore antibiotics. Curr Opin Microbiol 5:194-201

Brown RM, Willison JH, Richardson CL (1976) Cellulose biosynthesis in Acetobacter xylinum: visualization of the site of synthesis and direct measurement of the in vivo process. Proc Natl Acad Sci U S A 73: 4565-4569. https://doi.org/10.1073/pnas.73.12.4565

Caldas T, Laalami S, Richarme G (2000) Chaperone properties of bacterial elongation factor EF-G and initiation factor IF2. J Biol Chem 275:855-860. https://doi.org/10.1074/jbc.275.2.855

Cascales E, Gavioli M, Sturgis JN, Lloubes R (2000) Proton motive force drives the interaction of the inner membrane TolA and outer membrane Pal proteins in Escherichia coli. Mol Microbiol 38:904-915. https://doi.org/10.1046/j.1365-2958.2000.02190.x

Cascales E, Lloubès R, Sturgis JN (2001) The TolQ-TolR proteins energize TolA and share homologies with the flagellar motor proteins MotA-MotB. Mol Microbiol 42:795-807. https://doi.org/10.1046/j. 1365-2958.2001.02673.x

Chanliaud E, Gidley MJ (1999) In vitro synthesis and properties of pectin/Acetobacter xylinus cellulose composites. Plant J 20:25-35. https://doi.org/10.1046/j.1365-313X.1999.00571.x

Choy WK, Zhou L, Syn CKC, Zhang LH, Swarup S (2004) MorA defines a new class of regulators affecting flagellar development and biofilm formation in diverse Pseudomonas species. J Bacteriol 186: 7221-7228. https://doi.org/10.1128/JB.186.21.7221-7228.2004
Cielecka I, Szustak M, Gendaszewska-Darmach E, Kalinowska H, Ryngajłło M, Maniukiewicz W, Bielecki S (2018) Novel bionanocellulose/ $\mathrm{K}$-carrageenan composites for tissue engineering. Appl Sci 8:1352. https://doi.org/10.3390/app8081352

de Oliveira Barud HG, da Silva RR, da Silva BH, Tercjak A, Gutierrez J, Lustri WR, de Oliveira OB, Ribeiro SJL (2016) A multipurpose natural and renewable polymer in medical applications: bacterial cellulose. Carbohydr Polym 153:406-420

Donlan RM (2002) Biofilms: microbial life on surfaces. Emerg Infect Dis 8:881-890

Fang J, Kawano S, Tajima K, Kondo T (2015) In vivo curdlan/cellulose bionanocomposite synthesis by genetically modified Gluconacetobacter xylinus. Biomacromolecules 16:3154-3160. https://doi.org/10.1021/acs.biomac.5b01075

Fijałkowski K, Zywicka A, Drozd R, Niemczyk A, Junka AF, Peitler D, Kordas M, Konopacki M, Szymczyk P, El Fray M, Rakoczy R (2015) Modification of bacterial cellulose through exposure to the rotating magnetic field. Carbohydr Polym 133:52-60. https://doi. org/10.1016/j.carbpol.2015.07.011

Fraser GM, Hughes C (1999) Swarming motility. Curr Opin Microbiol 2: $630-635$

Froger A, Hall JE (2008) Transformation of plasmid DNA into E. coli using the heat shock method. J Vis Exp. https://doi.org/10.3791/253

Fukuoka H, Yakushi T, Kusumoto A, Homma M (2005) Assembly of motor proteins, PomA and PomB, in the Na+-driven stator of the flagellar motor. J Mol Biol 351:707-717. https://doi.org/10.1016/j. jmb.2005.06.037

Gallegos AMA, Carrera SH, Parra R, Keshavarz T, Iqbal HMN (2016) Bacterial cellulose: a sustainable source to develop value-added products - a review. BioResources 11:5641-5655. https://doi.org/ 10.15376/biores.11.2.Gallegos

Gaspar JA, Thomas JA, Marolda CL, Valvano MA (2000) Surface expression of O-specific lipopolysaccharide in Escherichia coli requires the function of the TolA protein. Mol Microbiol 38:262275. https://doi.org/10.1046/j.1365-2958.2000.02094.x

Gerding MA, Ogata Y, Pecora ND, Niki H, De Boer PAJ (2007) The trans-envelope Tol-Pal complex is part of the cell division machinery and required for proper outer-membrane invagination during cell constriction in E. coli. Mol Microbiol 63:1008-1025. https://doi.org/ 10.1111/j.1365-2958.2006.05571.x

Germon P, Ray MC, Vianney A, Lazzaroni JC (2001) Energy-dependent conformational change in the TolA protein of Escherichia coli involves its N-terminal domain, TolQ, and TolR. J Bacteriol 183: 4110-4114. https://doi.org/10.1128/JB.183.14.4110-4114.2001

Gray AN, Egan AJF, Van't Veer IL, Verheul J, Colavin A, Koumoutsi A, Biboy J, Altelaar AF, Damen MJ, Huang KC, Simorre J-P, Breukink E, den Blaauwen T, Typas A, Gross CA, Vollmer W (2015) Coordination of peptidoglycan synthesis and outer membrane constriction during Escherichia coli cell division. Elife 4. doi: https:// doi.org/10.7554/eLife.07118

Guttenplan SB, Kearns DB (2013) Regulation of flagellar motility during biofilm formation. FEMS Microbiol Rev 37:849-871

Hall PE, Anderson SM, Johnston DM, Cannon RE (1992) Transformation of Acetobacter xylinum with plasmid DNA by electroporation. Plasmid 28:194-200. https://doi.org/10.1016/0147619X(92)90051-B

Hölscher T, Bartels B, Lin YC, Gallegos-Monterrosa R, Price-Whelan A, Kolter R, Dietrich LEP, Kovács ÁT (2015) Motility, chemotaxis and aerotaxis contribute to competitiveness during bacterial pellicle biofilm development. J Mol Biol 427:3695-3708. https://doi.org/10. 1016/j.jmb.2015.06.014

Hossain MM, Shibata S, Aizawa SI, Tsuyumu S (2005) Motility is an important determinant for pathogenesis of Erwinia carotovora 
subsp. carotovora. Physiol Mol Plant Pathol 66:134-143. https:// doi.org/10.1016/j.pmpp.2005.06.001

Hossain MM, Tsuyumu S (2006) Flagella-mediated motility is required for biofilm formation by Erwinia carotovora subsp. carotovora. J Gen Plant Pathol 72:34-39. https://doi.org/10.1007/s10327-0050246-8

Islam ST, Mignot T (2015) The mysterious nature of bacterial surface (gliding) motility: a focal adhesion-based mechanism in Myxococcus xanthus. Semin Cell Dev Biol 46:143-154

Jacek P, Dourado F, Gama M, Bielecki S (2019) Molecular aspects of bacterial nanocellulose biosynthesis. Microb Biotechnol 0:1-17. https://doi.org/10.1111/1751-7915.13386

Jacek P, Szustak M, Kubiak K, Gendaszewska-Darmach E, Ludwicka K, Bielecki S (2018) Scaffolds for chondrogenic cells cultivation prepared from bacterial cellulose with relaxed fibers structure induced genetically. Nanomaterials 8:1066-1077. https://oi.org/10.3390/ nano8121066

Kearns DB, Losick R (2005) Cell population heterogeneity during growth of Bacillus subtilis. Genes Dev 19:3083-3094. https://doi. org/10.1101/gad.1373905

Koerdt A, Paulick A, Mock M, Jost K, Thormann KM (2009) MotX and MotY are required for flagellar rotation in Shewanella oneidensis MR-1. J Bacteriol 191:5085-5093. https://doi.org/10.1128/JB. 00206-09

Kojima S (2015) Dynamism and regulation of the stator, the energy conversion complex of the bacterial flagellar motor. Curr Opin Microbiol 28:66-71

Kojima S, Blair DF (2004) Solubilization and purification of the MotA/ MotB complex of Escherichia coli ${ }^{\dagger}$. Biochemistry. 43:26-34. https://doi.org/10.1021/bi0354051

Lee KY, Buldum G, Mantalaris A, Bismarck A (2014) More than meets the eye in bacterial cellulose: biosynthesis, bioprocessing, and applications in advanced fiber composites. Macromol Biosci 14:10 32. https://doi.org/10.1002/mabi.201300298

Little K, Austerman JL, Zheng J, Gibbs KA (2018) Swarming bacteria respond to increasing barriers to motility by increasing cell length and modifying colony structure

Liu R, Ochman H (2007a) Stepwise formation of the bacterial flagellar system. Proc Natl Acad Sci 104:7116-7121. https://doi.org/10. 1073/pnas.0700266104

Liu R, Ochman H (2007b) Origins of flagellar gene: operons and secondary flagellar systems. J Bacteriol 189:7098-7104. https://doi.org/10. 1128/JB.00643-07

Livak KJ, Schmittgen TD (2001) Analysis of relative gene expression data using real-time quantitative PCR and the 2- $\Delta \Delta \mathrm{CT}$ method. Methods. 25:402-408. https://doi.org/10.1006/meth.2001.1262

Luo H, Xiong G, Huang Y, He F, Wang Y, Wan Y (2008) Preparation and characterization of a novel COL/BC composite for potential tissue engineering scaffolds. Mater Chem Phys 110:193-196. https://doi. org/10.1016/j.matchemphys.2008.01.040

Madison KE, Abdelmeguid MR, Jones-Foster EN, Nakai H (2012) A new role for translation initiation factor 2 in maintaining genome integrity. PLoS Genet 8:e1002648. https://doi.org/10.1371/journal. pgen. 1002648

Maki-Yonekura S, Matsuoka R, Yamashita Y, Shimizu H, Tanaka M, Iwabuki F, Yonekura K (2018) Hexameric and pentameric complexes of the ExbBD energizer in the ton system. Elife. 7:e35419. https://doi.org/10.7554/eLife.35419

Merritt PM, Danhorn T, Fuqua C (2007) Motility and chemotaxis in Agrobacterium tumefaciens surface attachment and biofilm formation. In: Journal of Bacteriology. pp 8005-8014

Morimoto YV, Che YS, Minamino T, Namba K (2010) Protonconductivity assay of plugged and unplugged MotA/B proton channel by cytoplasmic pHluorin expressed in Salmonella. FEBS Lett 584:1268-1272. https://doi.org/10.1016/j.febslet.2010.02.051
Niba ETE, Naka Y, Nagase M, Mori H, Kitakawa M (2007) A genomewide approach to identify the genes involved in biofilm formation in E. coli. DNA Res 14:237-246. https://doi.org/10.1093/dnares/ dsm024

Noinaj N, Guillier M, Barnard TJ, Buchanan SK (2010) TonB-Dependent transporters: regulation, structure, and function. Annu Rev Microbiol 64:43-60. https://doi.org/10.1146/annurev.micro. 112408.134247

O’Toole GA, Kolter R (1998) Flagellar and twitching motility are necessary for Pseudomonas aeruginosa biofilm development. Mol Microbiol 30:295-304. https://doi.org/10.1046/j.1365-2958.1998. 01062.x

Okamoto-Kainuma A, Yan W, Fukaya M, Tukamoto Y, Ishikawa M, Koizumi Y (2004) Cloning and characterization of the dnaKJ operon in Acetobacter aceti. J Biosci Bioeng 97:339-342. https://doi. org/10.1016/S1389-1723(04)70216-9

Patrick JE, Kearns DB (2008) MinJ (YvjD) is a topological determinant of cell division in Bacillus subtilis. Mol Microbiol 70:1166-1179. https://doi.org/10.1111/j.1365-2958.2008.06469.x

Pfeffer S, Mehta K, Brown RM (2016) Complete genome sequence of a Gluconacetobacter hansenii ATCC 23769 isolate, AY201, producer of bacterial cellulose and important model organism for the study of cellulose biosynthesis. Genome Announc 4:e00808-e00816. https:// doi.org/10.1128/genomeA.00808-16

Picheth GF, Pirich CL, Sierakowski MR, Woehl MA, Sakakibara CN, de Souza CF, Martin AA, da Silva R, de Freitas RA (2017) Bacterial cellulose in biomedical applications: a review. Int J Biol Macromol 104:97-106

Postle K, Kadner RJ (2003) Touch and go: tying TonB to transport. Mol Microbiol 49:869-882

Pratt LA, Kolter R (1998) Genetic analysis of Escherichia coli biofilm formation: roles of flagella, motility, chemotaxis and type I pili. Mol Microbiol 30:285-293. https://doi.org/10.1046/j.1365-2958.1998. 01061.x

Ryan KR, Shapiro L (2003) Temporal and spatial regulation in prokaryotic cell cycle progression and development. Annu Rev Biochem 72:367-394. https://doi.org/10.1146/annurev.biochem.72.121801. 161824

Ryngajłło M, Kubiak K, Jedrzejczak-Krzepkowska M, Jacek P, Bielecki S (2018) Comparative genomics of the Komagataeibacter strainsefficient bionanocellulose producers. Microbiologyopen 26:e00731. 1-25. https://doi.org/10.1002/mbo3.731

Sano MB, Rojas AD, Gatenholm P, Davalos RV (2010) Electromagnetically controlled biological assembly of aligned bacterial cellulose nanofibers. Ann Biomed Eng 38:2475-2484. https:// doi.org/10.1007/s10439-010-9999-0

Santos CA, Janissen R, Toledo MAS, Beloti LL, Azzoni AR, Cotta MA, Souza AP (2015) Characterization of the TolB-Pal trans-envelope complex from Xylella fastidiosa reveals a dynamic and coordinated protein expression profile during the biofilm development process. Biochim Biophys Acta Proteins Proteomics 1854:1372-1381. https://doi.org/10.1016/j.bbapap.2015.05.018

Shapiro L, McAdams HH, Losick R (2002) Generating and exploiting polarity in bacteria. Science (80) 298:1942-1946

Shi W, Zhou Y, Wild J, Adler J, Gross CA (1992) DnaK, DnaJ, and GrpE are required for flagellum synthesis in Escherichia coli. J Bacteriol 174:6256-6263. https://doi.org/10.1128/jb.174.19.6256-6263.1992

Søgaard-Andersen L (2011) Directional intracellular trafficking in bacteria. Proc Natl Acad Sci U S A 108:7283-7284. https://doi.org/10. 1073/pnas. 1104616108

Sun M, Wartel M, Cascales E, Shaevitz JW, Mignot T (2011) Motordriven intracellular transport powers bacterial gliding motility. Proc Natl Acad Sci 108:7559-7564. https://doi.org/10.1073/pnas. 1101101108

Susin MF, Baldini RL, Gueiros-Filho F, Gomes SL (2006) GroES/GroEL and DnaK/DnaJ have distinct roles in stress responses and during 
cell cycle progression in Caulobacter crescentus. J Bacteriol 188: 8044-8053. https://doi.org/10.1128/JB.00824-06

Svensson A, Nicklasson E, Harrah T, Panilaitis B, Kaplan DL, Brittberg M, Gatenholm P (2005) Bacterial cellulose as a potential scaffold for tissue engineering of cartilage. Biomaterials 26:419-431. https://doi. org/10.1016/j.biomaterials.2004.02.049

Szurmant H, Ordal GW (2004) Diversity in chemotaxis mechanisms among the bacteria and archaea. Microbiol Mol Biol Rev 68:301319. https://doi.org/10.1128/MMBR.68.2.301-319.2004

Tamar E, Koler M, Vaknin A (2016) The role of motility and chemotaxis in the bacterial colonization of protected surfaces. Sci Rep 6:6. https://doi.org/10.1038/srep19616

Teleha MA, Miller AC, Larsen RA (2013) Overexpression of the Escherichia coli TolQ protein leads to a null-FtsN-like division phenotype. Microbiologyopen 2:618-632. https://doi.org/10.1002/ mbo3.101

Treuner-Lange A, Søgaard-Andersen L (2014) Regulation of cell polarity in bacteria. J Cell Biol 206:7-17. https://doi.org/10.1083/jcb. 201403136

Wang H, Zhang L, Silv AJ, Benitez JA (2013) A quinazoline-2,4-diamino analog suppresses vibrio cholerae flagellar motility by interacting with motor protein pomb and induces envelope stress. Antimicrob Agents Chemother 57:3950-3959. https://doi.org/10.1128/AAC. 00473-13

Watanabett K, Yamanaka S (1995) NII-electronic library service effects of oxygen tension in the gaseous phase on production and physical properties of bacterial cellulose formed under static culture conditions t. Biosci Biotechnol Biochem 59:65-68

Wu ZY, Liang HW, Chen LF, Hu BC, Yu SH (2016) Bacterial cellulose: a robust platform for design of three dimensional carbon-based functional nanomaterials. Acc Chem Res 49:96-105. https://doi.org/10. 1021/acs.accounts.5b00380

Yamanaka S, Ishihara M, Sugiyama J (2000) Structural modification of bacterial cellulose. Cellulose 7:213-225. https://doi.org/10.1023/A: 1009208022957

Yamanaka S, Watanabe K, Kitamura N, Iguchi M, Mitsuhashi S, Nishi Y, Uryu M (1989) The structure and mechanical properties of sheets prepared from bacterial cellulose. J Mater Sci 24:3141-3145. https:// doi.org/10.1007/BF01139032

Yeh YC, Comolli LR, Downing KH, Shapiro L, McAdams HH (2010) The Caulobacter Tol-Pal complex is essential for outer membrane integrity and the positioning of a polar localization factor. J Bacteriol 192:4847-4858. https://doi.org/10.1128/JB.00607-10

Zhong C, Zhang GC, Liu M, Zheng XT, Han PP, Jia SR (2013) Metabolic flux analysis of Gluconacetobacter xylinus for bacterial cellulose production. Appl Microbiol Biotechnol 97:6189-6199. https://doi. org/10.1007/s00253-013-4908-8

Publisher's note Springer Nature remains neutral with regard to jurisdictional claims in published maps and institutional affiliations. 